\title{
Eco-innovation and retailers in milk, beef and bread chains: enriching environmental supply chain management with insights from innovation studies
}

\author{
J. Mylan a, b, *, F.W. Geels ${ }^{\text {a, b }}$, S. Gee ${ }^{\text {a, b }}$, A. McMeekin ${ }^{\text {a }}$, C. Foster ${ }^{b}$ \\ a Sustainable Consumption Institute, 188 Waterloo Place, Oxford Road, University of Manchester, UK \\ ${ }^{\mathrm{b}}$ Institute of Innovation Research, Manchester Business School, University of Manchester, UK
}

\section{A R T I C L E I N F O}

\section{Article history:}

Received 8 November 2013

Received in revised form

7 August 2014

Accepted 3 September 2014

Available online 16 October 2014

\section{Keywords:}

Eco-innovation

Distributed innovation

Supply chain

Agri-food

Supermarket

\begin{abstract}
A B S T R A C T
This paper investigates why, how and to what degree supermarkets stimulate upstream eco-innovation in UK milk, beef and bread chains. To answer this question, we aim to enrich the environmental supply chain management literature with insights from innovation studies. The resulting conceptual framework distinguishes three elements: a) motivations for supermarkets to address eco-innovation (internal considerations and external pressures), b) characteristics of supply chains that hinder or enable ecoinnovation attempts (e.g. breadth, length, degree of trust), c) mechanisms to stimulate eco-innovation. Regarding this third element, which is our main contribution, we distinguish: 1) economic mechanisms (supermarkets paying farmers more for eco-innovation or imposing eco-performance standards), 2) information exchange and interactive learning in networks ('innovation systems'), and 3) sociocognitive coordination through the creation of shared meaning and visions (e.g. roadmaps). We demonstrate the usefulness of this framework with a comparative qualitative analysis of three UK sectors with different degrees of retailer-led eco-innovation: milk, beef and bread. The paper ends with three broader reflections and suggestions for further research.
\end{abstract}

() 2014 Published by Elsevier Ltd.

\section{Introduction}

Food production and consumption have major environmental implications, accounting for about $22 \%$ of UK greenhouse gas emissions (Defra, 2010). It is therefore important to improve the understanding of eco-innovation in food supply-chains, which is the general aim of this paper. We adopt the European Commission's definition of eco-innovation as: "the production, assimilation or exploitation of a novelty in products, production processes, services or in management and business methods, which aims, throughout its lifecycle, to prevent or substantially reduce environmental risk, pollution and other negative impacts of resource use (including energy)". A specific problem of eco-innovation in food is the "distance' between the production of environmental impacts and the power within the supply chain. While a significant proportion of the ecological problems in food are linked to primary production (farming), it is supermarkets which are the most powerful actors in terms of the governance of food chains (Dolan and Humphrey,

\footnotetext{
* Corresponding author. Institute of Innovation Research, Manchester Business School, University of Manchester, UK. Tel.: +44 01612752456.
}

E-mail address: josephine.mylan@manchester.ac.uk (J. Mylan).
2000). We therefore analyse eco-innovation in food chains as a distributed process, focussing on coordination mechanisms used by supermarkets to stimulate upstream eco-innovation in farming. Another consideration is that the structure and governance of foodchains vary substantially between different commodities (Fine et al., 1996). The paper therefore aims to go beyond the single case studies that permeate the debates on eco-innovation and environmental supply chain management.

The research question addressed is: Why, how and to what degree do supermarkets stimulate upstream eco-innovation in agri-food supply chains? We compare UK milk, beef and bread chains, because, despite a concentration of environmental impact at the agricultural stage of production, they differ substantially in the eco-innovation efforts coordinated by supermarkets. These differences, both in terms of degree of activity (relatively large in milk, moderate in beef, small in bread) and approach, provide contrasts that we aim to explain.

To answer this question, we build on the environmental supply chain management (ESCM) literature, but aim to enrich this literature with insights from innovation studies. The motivation for this is that ESCM, which offers many relevant insights (see Section 2), is under-developed in three respects. Firstly, although the ESCM- 
literature has usefully identified factors that motivate actors to engage in eco-innovation ('why'), it has paid less attention to the process ('how') of eco-innovation in supply chains (Van Bommel, 2011). Secondly, ESCM has a relatively limitedly theoretical grounding in social science literatures. The highly cited review paper by Seuring and Müller (2008: 1702), for instance, concludes that the ESCM literature suffers from a "deficit in the take-up of theoretical backgrounds" and "needs to build on a stronger theoretical basis". Thirdly, ESCM is sophisticated in the understanding of dyadic relations in supply chains, but less developed in the understanding of interactions across longer chains. To address these three issues, the paper imports insights from innovation studies into ESCM with the aim of providing a deeper understanding of the eco-innovation process and providing more theoretical grounding for understanding distributed innovation (focussing particularly on mechanisms used by supermarkets to stimulate upstream adoption of green novelty). Our general claim is that the different kinds of interactions between actors in the supply chain and varying prevalence of innovation and coordination mechanisms helps explain differences between the three cases.

The paper is structured as follows: Section 2 briefly describes our conceptual framework, which aims to combine insights from ESCM and innovation studies. Section 3 discusses methods and data. Section 4 describes three case studies of eco-innovation in the milk, beef, and bread sectors. These case studies address the orientations and eco-innovation strategies of supermarkets in the context of pre-existing supply chain arrangements. Section 5 makes an analysis of the three cases, and explains the differences. The paper ends with concluding comments in Section 6.

\section{Conceptual framework}

This section does not aim for an extensive overview of the ESCM literature, nor for a comprehensive synthesis with the field of innovation studies. Instead, it introduces concepts that can be used for the empirical analysis. Analytically, we introduce concepts to understand: a) motivations for supermarkets to address ecoinnovation ('why'), b) characteristics of supply chains that hinder or enable eco-innovation attempts, c) mechanisms to stimulate eco-innovation ('how').

a) The dominant role of supermarkets operating as "lead firms" controlling food supply chains is well documented (Dolan and Humphrey, 2000). Retailers can use their power to capture increasing amounts of the value in agro-food chains (Gereffi et al., 2005). As a consequence retailers often put pressure on suppliers to reduce costs, which may lead to antagonistic and distrustful relations. They can also use their position to work more collaboratively with suppliers to stimulate eco-innovation. So, the kinds of interactions in chains can vary, depending on lead firm strategies and sector characteristics.

Much of the ESCM-literature has focused on why greening takes place, i.e. motivations (Srivastava, 2007; Seuring and Müller, 2008). On the one hand, the literature emphasises the importance of external factors such as legislative pressure, customers' requirements, pressure from the public and from environmental advocacy groups. On the other hand, it emphasises internal considerations such as cost reduction (e.g. eco-efficiency measures that offer win-win solutions), belief that environmental issues will become important for consumers or policymakers, and reputational and defensive reasons: firms may voluntarily engage in ecoinitiatives to "pre-empt potential negative effects of not dealing adequately with a widely salient issue such as climate change, $(. .$. oppose demands from activists or interests groups, or (...) forestall future regulations" (Kolk and Pinkse, 2007: 201).

b) Although supermarkets are powerful actors, they are not allpowerful, autonomous supply chain managers. They are better seen as embedded actors whose ability to stimulate upstream eco-innovation also depends on strategies and interests of other actors, sector structure, and degrees of supply chain integration. A key insight from ESCM is that pre-existing chain structure matters for coordination. Omta (2001) distinguishes between the breadth of a supply network (number of suppliers and customers) and length (number of tiers in a chain or network as shown in Fig. 1). It will be more difficult for supermarkets to coordinate and stimulate upstream eco-innovation in longer networks with greater breadth (i.e. number of farmers). Longer chains also tend to have more intermediary actors, which may complicate coordination by supermarkets if these intermediary actors are reluctant or have their own agendas.

The ability of supermarkets to stimulate upstream ecoinnovation also depends on existing tensions, relations and governance modes. With regard to governance modes, Gereffi et al. (2005) emphasised that different chains may be dominated by different kinds of interactions and associated modes of coordination, which correspond to varying degrees of lead-firm control. The extent to which interactions are based on formal or relational contracting is also expected to influence opportunities for distributed innovation (Powell and Grodal, 2005). Both perspectives indicate that pre-existing relations, tensions and governance modes are likely to influence both the motivations of supermarkets to stimulate upstream eco-innovation and the kinds of preferred innovation mechanisms.

c) Van Bommel (2011) made an important step by distinguishing three approaches that pay attention to how supply-chain ecoinnovation is enacted: a) technological/economical approaches, which focus on managing flows of materials, money and other resources, b) network and inter-organisational perspectives, which focus on cooperation and interactions, c) socio-cultural perspectives, which focus on normative and interpretive schemes shared in social systems. We aim to make a next step by linking Van Bommel's suggestions more firmly to different theoretical frameworks, thus also addressing Seuring and Müller's (2008) criticism that ESCM has insufficient theoretical grounding. While innovation studies generally conceptualises innovation as a collective and interactive process, we distinguish

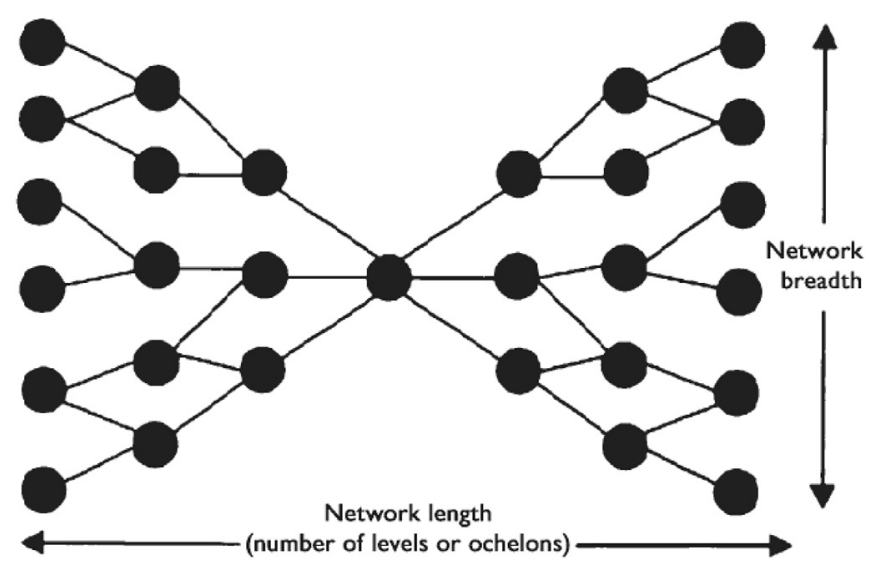

Fig. 1. Length and breadth of supply network with central position of lead firm (Omta, 2001:3). 
three specific theories which highlight different mechanisms for innovation and coordination between dispersed actors.

1) The approach of evolutionary economics (Freeman and Soete, 1997) conceptualises innovation as an uncertain and risky process, enacted by firms facing market selection pressures. Firm's investment decisions in product and process innovations result in variations (in product characteristics or prices) from which markets select (Dosi and Nelson, 1994). Products with a better fit are selected, enabling the associated firms to reproduce themselves. The evolutionary logic can be applied to supply chains by conceptualising downstream firms as providing economic selection environments for upstream firms. The implication is that retailers can shape upstream eco-innovation through their buying power, which creates economic selection pressure throughout the chain. This kind of economic coordination can take several concrete forms: supermarkets pay more for ecoinnovations (which enables upstream actors to make ecoinvestments), they can provide longer-term contracts for farmers who implement eco-innovation (which reduces investment risks), or they can formulate eco-standards that suppliers should meet (Van den Bergh et al., 2008).

2) The innovation systems approach conceptualises innovation as an interactive process between actors in a (sectoral) system (universities, firms, research institutes, standard bodies, dissemination agencies), with a focus on information exchange and interactive learning (Lundvall, 1992; Malerba, 2002). The innovation system approach focuses on the flows of knowledge and information through social networks and the social interactions that facilitate learning about the technology (performance, cost, design) and the market (consumer preferences, applications). Innovation is positively influenced by integrated cohesive networks with trust-full relationships (Gambetta, 1988) which stimulate actors to collaborate and share experiences. For innovation in supply chains this approach highlights the importance of information exchange across multiple links in the chain, which is facilitated by collaborations between upstream and downstream actors. Information exchange can concretely be facilitated by bench-marking, demonstration projects, best practice guidelines, and information dissemination initiatives (e.g. leaflets, reports, websites, consultants). Collective bodies such as industry associations can also help disseminate information to their members.

3) The sociology of innovation focuses less on 'information' and more on the cognitive content of the beliefs of different actors (Howells, 1995). The social construction of technology (SCOT) approach (Bijker et al., 1987), for example, argues that early stages of innovation are characterised by interpretive flexibility', which means that actors have different views and visions about the technology. Discussions, debates, and social learning gradually lead to 'cognitive closure' and the creation of shared meanings, which stimulate innovation by reducing uncertainty. The sociology of expectations approach (Van Lente, 1993; Borup et al., 2006) further argues that shared expectations and future visions enhance innovation by providing a sense of direction to innovation actors and by attracting attention and funding from external actors. In supply chains, the emergence of shared meanings, beliefs and visions can be stimulated through debates in workshops, conferences, platforms, and journals. Collective bodies (such as industry associations) can also play a productive role by bringing actors together and facilitating collective sense making.

These three different theories highlight different coordination mechanisms through which supermarkets can stimulate upstream eco-innovation: a) market demand, b) information exchange through networks, c) socio-cognitive coordination through shared meanings and visions. We propose that the deployment of these mechanisms by supermarkets is shaped both by their motivations and pre-existing supply chain characteristics. The next section will use these concepts to describe and analyse three eco-innovation case studies.

\section{Methods and data}

The case studies were conducted as part of a 2-year research project of the Sustainable Consumption Institute (2010-2012). We adopted a case study approach because this methodology is suited to study complex phenomenon in real-life contexts with many interacting variables (Yin, 1994). We chose a comparative research design, in order to show how different combinations of variables lead to different results in the three sectors. We selected three cases (milk, beef and bread) which represent supply chains with different degrees of retailer-involvement in stimulating eco-innovation.

Data were collected from secondary sources including industry publications, market research data and environmental reports of relevant organisations, and via semi-structured interviews with 47 people (including retailers, processors, industry bodies, suppliers of agricultural inputs, agricultural consultants, R\&D organisations) across the three sectors (see Appendix 1).

The case study process proceeded through several iterations of data collection and interpretation. The first-round analysis reviewed food policy documents, market research data and past and ongoing sustainability initiatives to develop a general understanding of the structure of the three sectors and the key dynamics with respect to sustainability. The second-round analysis deepened this understanding through stakeholder interviews, aimed at gaining additional insights into key events and industry dynamics. The semistructured interviews asked interviewees to recount significant industry changes in the past 20 years, key environmental problems, and efforts to address these. The third-round analysis focussed on various eco-innovations and the variables from our conceptual framework. We analysed documents of specific initiatives and performed stakeholder interviews, which were conducted either face to face or by telephone using a semi-structured interview format. Most interviews were recorded and transcribed, except when interviewees refused permission, in which case notes were taken during the interview and written up more fully directly afterwards. All interviews included questions covering the following three key areas (while allowing follow-up questions depending on an individual's area of expertise): 1) Changes in technology or production arrangements within the supply chain that aimed to reduce environmental impacts, and how and why these had come about, 2) Relationships between the organisations within the supply chains, how these enabled or constrained change, particularly with respect to retailers, 3) Measures or initiatives imposed by any actors (particularly retailers) on other members of the supply chain which enabled or constrained change toward more sustainable production arrangements; how and why these had been effective.

\section{Eco-innovation in three sectors}

The accounts of the three case studies are necessarily condensed, focussing on key aspects in supermarket strategies and supply chains. While the cases show some variety in individual supermarket strategies, space limitations preclude in-depth discussion of this. The case descriptions therefore sometimes treat 'the supermarkets' as a coherent sector-level category.

Below, we first describe how 'external' pressures (from policymakers, NGOs, consumers) on supermarkets play out differently in the three cases. Three subsequent sections then discuss each case 
(milk, beef, bread) individually, describing how and why supermarkets responded to external pressures in the context of supply chain arrangements.

The UK government broadly practices a hands-off approach with regard to regulation of eco-innovation farming practices. Defra (Department for Environment, Food, and Rural Affairs) has however exerted indirect pressure for innovation through reports that document the scale of environmental problems and foresight exercises that highlight the need and possibilities for major changes, e.g. Food 2030 (Defra, 2010) and Progress towards a sustainable future for livestock living (Defra, 2012). Attempting to work with industry, Defra often includes industry actors in these exercises. Following the 2008 Climate Change Act, Defra stimulated various sectors to develop roadmaps to explore concrete sustainability pathways, including Milk and Beef. In the case of bread, aside from guidelines on fertiliser use efficiency, influence is restricted to research funding on wheat varieties (e.g. the Wheat Genetic Improvement Programme and the Grain Protein Deviation Programme). However, these 'science-push' efforts face problems in wider uptake, of lack of demand and limited information flows, due to fragmented supply base, as discussed below.

The European Common Agricultural Policy (CAP) forms an important part of the context within which UK farmers operate, providing income support, supply controls and border measures. However, there is little evidence to suggest that CAP payments to farmers, which since 2003 require greater compliance with environmental standards, have been significant in promoting ecoinnovation in any of the three cases. In the case of beef, in which CAP payments can contribute over $50 \%$ of total farm income for some types of farms, the main contribution may have been to dampen signals from downstream actors, contributing to the maintenance of existing farming practices.

Pressure from Non-Governmental Organisations such as Friends of the Earth and the WWF has been exerted on the Milk and Beef sectors through the commissioning of critical reports that advocate radical changes in production. Two WWF-sponsored reports (Audsley et al., 2009; Jackson et al., 2009) not only recommend radical innovations, but also substantial changes in diets, including less consumption and shifts to substitute products (e.g. artificial meat, soy-milk). NGOs thus exert normative pressures for change on a range of 'issues' in Milk and Beef production including landscape management and biodiversity, animal welfare, and climate change. In contrast, NGO attention to bread production is limited to concerns over health, which has resulted in significant decline in salt content of UK produced bread in recent years.

Most UK consumers pay relatively limited attention to environmental sustainability implications of food and do not explicitly demand environmental improvements in production. Where concerns over food production do exist, they are largely associated with issues of health, safety, and provenance. The strategies through which supermarkets and producers have addressed these concerns vary across the three cases. In the case of milk, the response has been the introduction of low-fat and health-oriented products in supermarkets (Dairy UK, 2012). In the case of bread, supermarkets have invested extensively in the capacity for on-site production of 'fresh' baked produce, while branded producers strategies include regional branding (e.g. 100\% British wheat) and enriching new products with more 'healthsome' attributes, such as added vitamins, minerals and wholegrains. Consumer awareness of environmental issues is most evident in the case of beef, where it has been interpreted by supermarkets as consumers' associations with outdoor livestock rearing. The main response has been a focus on regional branding and 'nature' in beef marketing (Interviews 1 , $3,10)$. The recent 'horsemeat scandal' has, however, drawn attention to issues of supply chain traceability, prompting many UK

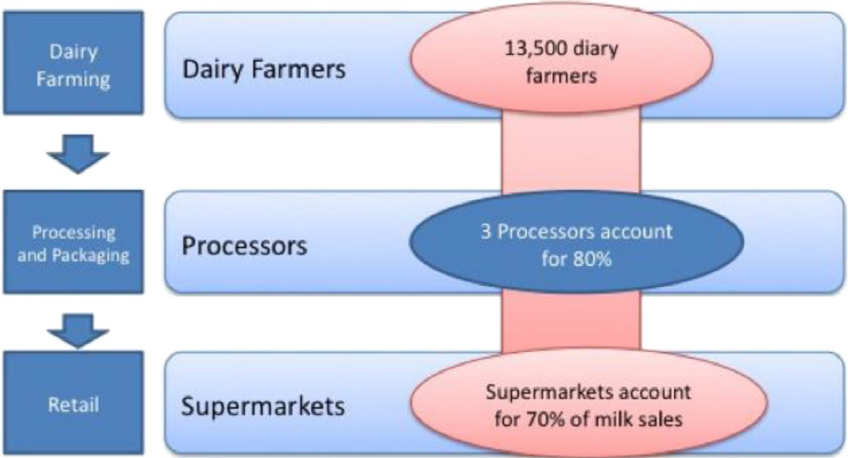

Fig. 2. Schematic sector structure and supply chain in UK milk.

supermarkets to release declarations of intent to build stronger relationships with UK beef farmers.

Pressures from government, NGOs and consumers form the context within which supermarkets engage with their supply chain and the wider industry in their attempts to simulate ecoinnovation. Supermarket responses to these pressures, in terms of the degree of effort and strategies used, depend on the specific relationship with the product category and the existing supply chain structure, as outlined in the following sections.

\subsection{Milk}

Dairy farmers have started implementing eco-innovations, in response to supermarket supply group initiatives and Milk Roadmap targets. The Dairy UK's 2012 White Paper claims that "the dairy industry (...) has been at the forefront of agriculture in recent years with regard to the drive towards environmental excellence" (p. 14). Most of the 2010 targets for farmer uptake of eco-innovation measures, agreed by the industry and set out in the Milk Roadmap (2008), have been met. These 2010 targets include: manure management plan (95\%) water use efficiency measures (5-15\%), nutrient management planning (65\%), trialling new technologies to reduce emissions from agriculture (20-30\%). Only targets concerning more radical innovation, e.g. uptake of on-farm anaerobic digestion, have not been met (only 9 pilots, compared to target of 30 , in place by 2010). ${ }^{1}$ This success of the 2008 Milk Roadmap galvanised the creation of the 2010 Dairy Roadmap with more challenging targets for 2015 and 2020.

The Milk Roadmap (2008), the Dairy Roadmap (2010) and the industry organisations which developed these (DairyCo and Dairy UK) played an important role in enabling eco-innovation in the Milk industry. In the context of multiple pressures for change, around different issues, the roadmaps provided clarity and reduced uncertainty. The process of development, led by industry bodies, included representatives of all actors in the industry. This helped to create buy-in and a degree of trust between different actors. Forging agreement amongst actors about problems, targets and future visions for eco-innovations, and provided socio-cognitive coordination.

Supermarkets' instrumental role in stimulating eco-innovation in dairy farming is evidenced by the distribution of ecoinvestment, which is concentrated among the top-quartile performing farms and corresponds to supplier groups which receive

\footnotetext{
1 Anearobic digesters are considered radical innovations because 1) they require farmers to learn new (chemical) competencies and 2) they frequently require new organisational arrangments to be established between farms enabling them to share capacity.
} 
premium payments from supermarkets (Dairy Roadmap, 2010). This pro-active approach to eco-innovation in the milk sector can be understood as a response to external pressures for action (from government, NGO and industry bodies), mediated by internal considerations of benefits of and feasibility to exert influence for change. Supermarkets view milk as a strategically important product; for many it represents the largest food category by sales value (Interview 2). The majority is sold as 'own-label', which enables them to capture more value and exert greater control over the supply chain. In addition, the milk supply chain is relatively simple (see Fig. 2), consisting of three main actor groups: farmers; processors; and supermarkets. So when faced with external pressures, supermarkets saw an opportunity to respond, taking advantage of their powerful position in the chain. Pre-existing supply groups were used as a vehicle to stimulate eco-innovation (Interview 41; Interview 6). This supply chain organisation emerged after the long-term depression of milk prices caused by supermarkets when the Milk Marketing Board (which set prices for farmers) was abolished by the Agriculture Act of 1993. Following highly-publicised protests about milk prices in 2005 and debates about pricing strategies, most supermarkets started paying more for milk, while some also offered long-term purchasing commitments to selected suppliers in exchange for secure supply. These new relationships enhanced integration as noted by an interviewee: "There is more integration in the dairy sector than the beef sector, retailers are connecting with farmers to secure supply" (Interview 39).

By 2012, around 3000 dairy farmers had special deals and linkages with supermarkets, which enabled them to invest and modernise (House of Commons, 2012). Compared to beef, supermarkets found it easier to establish these long-term commercial arrangements because of the fit with a stronger financial orientation in dairy farming: "Dairy farmers are basically business men, unlike the more traditional family run arrangements found in beef farming. Business men talk about their return, whereas in beef farming it's about how much do I get for an animal, rather than (...) the cost of production" (Interview 7).

Some prominent schemes are the Tesco Sustainable Dairy Group (about 700 members), Sainsbury Dairy Development Groups (about 320 members), and Co-op Dairy Group (about 220 members). The secure longer term relationships were noted by interviewees as contributing to the different context which enabled retailers to exert greater influence to promote sustainability.

Within this context, supermarkets have been able to successfully stimulate eco-innovation, though supplier groups, using two key mechanisms. 1) They have used economic mechanisms, through which supermarkets pay premium prices to farmers who meet certain environmental criteria, enabling them to further invest in eco-innovations, and 2) they have built networks and stimulated information flows, disseminating best practice information amongst members of supplier groups, measuring and benchmarking environmental footprints of farmers, and providing feedback and suggestions for improvement.

\subsection{Beef}

Eco-innovation in the beef sector has made limited progress compared to the dairy sector (Defra, 2012), despite comparable 'external' pressures and level of industry participation in development of industry 'Roadmaps'. ${ }^{2}$ As expressed by one agricultural consultant, the lower attention for environmental problems partly stems from serious financial problems in beef farming:

\footnotetext{
${ }^{2}$ Roadmap development in the beef sector was led by EBLEX, the organisation for beef and lamb levy payers.
}

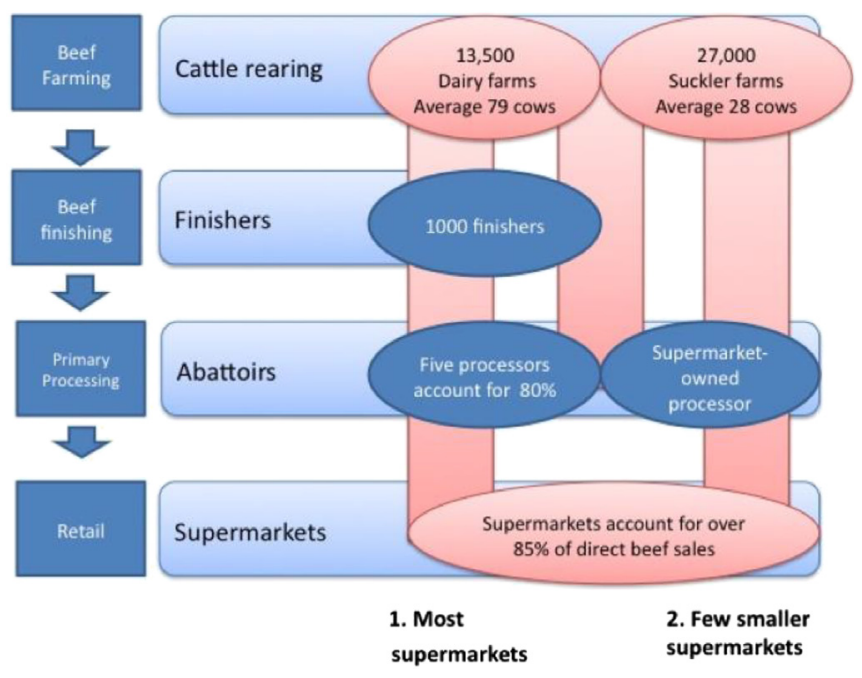

Fig. 3. Schematic sector structure and supply chain in UK beef.

"Environmental issues are less important in beef than in dairy ... .what happens in dairy takes 5-7 years to filter to beef. The main problem in beef is profitability ..." (Interview 38). Farms vary in the uptake of eco-innovations. Many 'finishing farms', where cows are fattened to market weight (the most profitable stage of beef farming, (EBLEX, 2009a)), are exemplars of best practice, and have closest relationships with upstream suppliers. Amongst the (less profitable) 'suckler farms', which raise and nurture calves, there are only few examples of eco-innovation adoption, which occur mainly in the context of direct support from retailers, which is relatively rare.

Supermarkets engage in eco-innovation to differing degrees, reflecting the differing supply chain structures and degree of strategic importance of beef between different supermarkets (which is higher for smaller supermarkets which use beef to attract consumers). Although the majority is sold as 'own-label', beef is of low commercial importance to most supermarkets, reflecting its high substitutability on the part of consumers, as well as a general decline in red meat consumption. The beef supply chain (see Fig. 3) is more complex than the milk supply chain, and there is greater variety in production arrangements. Supermarkets are supplied by multiple production systems, underpinned by different supply chain structures consisting of three or four tiers. UK beef is produced from cows bred and raised specifically for beef (sucklers, from many small scale farms) and from the male offspring of dairy cows (from larger scale dairy farms). Dairy calves are transferred to finishing farms, and all beef passes through primary processors, the "fulcrum of the supply chain" (Interview 24), which act as intermediaries between retailers and farmers. Their powerful position to exert influence means that they are frequently important in coordinating sustainability programmes for retailers, as well as leading development of sustainability programmes often in conjunction with external organisations, such as environmental consultancies.

In this context it is the smaller supermarkets, which over-trade in beef, that are most actively promoting eco-innovation (Foster and Gee, 2013). These smaller supermarkets often differentiate on quality rather than price, pay more for beef, and have more integrated supply chains, which also include ownership or exclusive relationships with processors and longer-term relationships with farmers or dedicated producer groups (Interviews 3 and 10). Consequently, these supply chains are shorter and the degree of retailer coordination is higher. These smaller supermarkets also pay premium prices to farmers who meet certain environmental 
criteria, and they engage in demonstration projects, benchmarking and communication of best practice (e.g. through knowledge transfer events and expert consultants). This contrasts with the largest supermarkets that have more complex supply chains with indirect, short-term and more adversarial relationships with farmers (Simons et al., 2003; EBLEX, 2010; Interview 18). The largest supermarkets do not pay extra for environmental standards or engage in agricultural R\&D (Interviews; Independent consultant, 2010). While there are examples of initiatives to stimulate collaboration and information dissemination, these remain small-scale and fragmented. ASDA's National Suckler Development, for example, involves only twelve farmers (Farmers Guardian, 2010). This lack of integration in the beef sector negatively influences the uptake of eco-innovations as one interviewee explains: "The beef industry would benefit from change but this doesn't happen easily ... It is very fragmented so what (farmers) do on one farm doesn't manifest itself in other farms" (Interview 38).

A range of factors contribute to the lack of meaningful engagement by most supermarkets in stimulating eco-innovation in the beef chains. In addition to supply chain features, long term decline in beef production, falling 25\% between 1985 and 2009 (Defra statistics, 2013), has resulted in economic insecurity among beef farmers. Today, the average suckler farmer makes negative net margins (Defra statistics, 2013). This has consequences for farmer investment in eco-innovation, which is further constrained by adversarial relationships and mistrust between farmers and retailers. Retailers blame these poor relations on beef farmers, which are deemed to have less professional financial orientations than dairy farmers (as indicated by the Retailer quote in the milk case).

In recognition of low farm income as a constraint on farmer investment in eco-innovation, the approach to sustainability presented in the Beef Roadmap focuses on linking economic efficiency with reduced GHG emissions (e.g. EBLEX, 2009b). However, reflecting the diverse interests within the industry, the Roadmap has not successfully presented one overarching vision on the future of sustainability. In addition, external pressures have precipitated a large number single issue schemes (such as agronomy, nutrient management, breeding or animal husbandry). One of our interviewees (Interview 20) expressed confusion through this variety, complaining about a "blanket of initiatives ... never ending ... so many that there is not one list ... it is bewildering and the focus constantly changes". These competing visions of sustainability serve to increase uncertainty, rather than acting as a coordinating mechanism as in the Milk case. In sum, supermarket-led ecoinnovation is limited in the case of the beef supply chain, because of low economic viability of beef farming, adversarial relationships in most supply chains and the absence of a coordinating vision of what sustainability means for beef production.

\subsection{Bread}

Supermarkets do little to stimulate eco-innovation in the upstream bread chain, viewing it as the responsibility of other actors, such as branded bakeries and farmers. The majority of bread sold in supermarkets is branded, which means that supermarkets have different relations with suppliers than in the milk and beef cases. Although bread is strategically important in attracting consumers into stores (Interview 9; Interview 28), sales generate little profit. Supermarkets' use of "discounting" strategies to attract consumers to stores has created considerable tensions between supermarkets and bakers, as discounted bread prices squeeze bakeries, resulting in declining profits over the past two decades (Interview 17; Interview 27).

The bread chain's width (17.000 farmers) is comparable to milk, but the number of tiers is greater (five) than in the milk and beef chains. Furthermore, the chain lacks mechanisms for communication between farmers and downstream actors (bakers, supermarkets), because relations between farmers and supermarkets are mediated by merchants and other economic intermediaries and therefore dominated by economic mechanisms (see Fig. 4). Firms in the relatively concentrated milling and bakery sectors do not use their economic power to stimulate eco-innovation throughout the chain, as one senior manager explained "However big we are, our ability to drive change in the agricultural industry is quite limited" (Interview, 30). There is also limited socio-cognitive coordination in the bread chain with neither customers nor supermarkets articulating clear expectations regarding environmental sustainability. "If you look across the framework of recommendations by our customers and the like, and even by the retailers, I think some of them are still a bit woolly. So it's difficult to comply with something that is woolly" (Interview 26). The relative absence of the three innovationcoordination mechanisms helps explain why branded bread manufacturers and retailers undertake only limited efforts to stimulate eco-innovation.

The exception is Warburtons, which has embarked on a concerted effort to stimulate eco-innovation in wheat production, through shaping growing practices. This effort has been driven by the strong internal commitment of senior management (Interview 32) and has been enabled by Warburtons' unique supply arrangements, which include long-term agreements with farmers, enabling influence via two mechanisms. Firstly, they demand particular standards for wheat farming including nitrogen application. Secondly, they facilitate knowledge transfer and sharing of best practice between farmers, through workshops and roadshows (Interview 32). These close relationships, combined with guaranteed markets, have helped overcome the widespread belief that fertilisers are the foundation to maximising productivity and profitability, a key constraint for uptake of practices that reduce fertiliser use (Interview 46).

Several research institutes engage in fundamental scientific research to develop nitrogen-efficient crops, including wheat. These institutes are funded by both government and plant breeding firms. However, nitrogen efficiency is not a priority for commercial

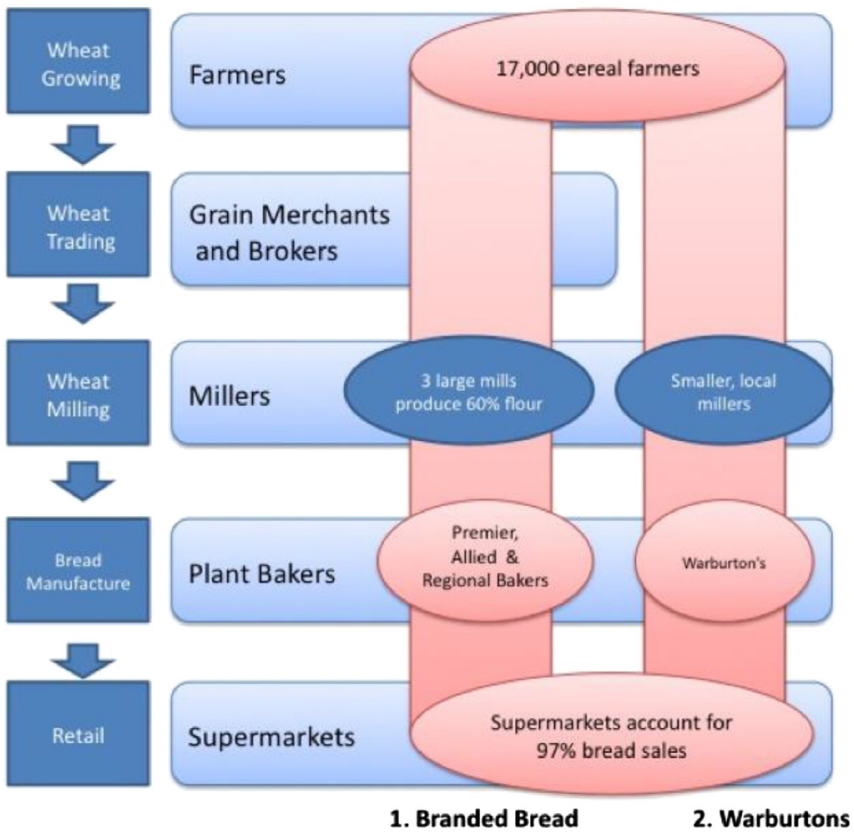

Fig. 4. Schematic sector structure and supply chain in UK bread. 
Table 1

Analytical summary of the three cases.

\begin{tabular}{|c|c|c|c|}
\hline & Milk & Beef & Bread \\
\hline $\begin{array}{l}\text { Supermarket engagement in agricultural } \\
\text { eco-innovation }\end{array}$ & Most & Some & Little \\
\hline \multicolumn{4}{|l|}{ 1) Supermarket motivation } \\
\hline a) External pressures & Strong & Moderate & Weak \\
\hline $\begin{array}{l}\text { Sector-specific attention to sustainability } \\
\text { from policymakers, NGOs and } \\
\text { consumers }\end{array}$ & Most & Some & Little \\
\hline $\begin{array}{l}\text { Degree of consensus regarding } \\
\text { sustainability issue to be addressed }\end{array}$ & $\begin{array}{l}\text { High: climate change focus; } \\
\text { but, also economic } \\
\text { sustainability of sector }\end{array}$ & $\begin{array}{l}\text { Low: multiple sustainability issues } \\
\text { without clear priorities; also } \\
\text { economic sustainability, } \\
\text { health and food safety }\end{array}$ & $\begin{array}{l}\text { Low: climate change, but also health } \\
\text { and nutrition, provenance }\end{array}$ \\
\hline b) Internal considerations & High & Low & Low \\
\hline Branded product or supermarket label & Supermarket label & Supermarket label & Branded product \\
\hline $\begin{array}{l}\text { Strategic significance of product for } \\
\text { supermarkets (switching product, } \\
\text { enticing consumers) }\end{array}$ & High & Low & High \\
\hline \multicolumn{4}{|c|}{ 2) Coordination and eco-innovation mechanisms (connecting supermarkets to farmers) } \\
\hline Economic & $\begin{array}{l}\text { Several economic mechanisms } \\
\text { (long-term contracts, pay more } \\
\text { for eco-innovation, formulate } \\
\text { eco-standards) }\end{array}$ & $\begin{array}{l}\text { Some economic mechanisms } \\
\text { (supermarkets pay more for } \\
\text { environmental standards) }\end{array}$ & $\begin{array}{l}\text { No economic mechanisms by } \\
\text { supermarkets. Only Warburtons } \\
\text { bakery has longer-term contracts } \\
\text { to simulate eco-innovation }\end{array}$ \\
\hline $\begin{array}{l}\text { Collaboration and information } \\
\text { dissemination }\end{array}$ & $\begin{array}{l}\text { Substantial collaboration and } \\
\text { information exchange in supplier } \\
\text { groups (benchmarking, best } \\
\text { practice dissemination) }\end{array}$ & $\begin{array}{l}\text { Some collaboration by smaller } \\
\text { supermarkets. Information exchange } \\
\text { through demonstration projects } \\
\text { and in supplier groups. }\end{array}$ & $\begin{array}{l}\text { None in use by supermarkets. } \\
\text { Some examples of bakers sharing } \\
\text { best practice between farmers. }\end{array}$ \\
\hline Socio-cognitive coordination & $\begin{array}{l}\text { Milk and dairy roadmaps with } \\
\text { strong industry buy-in. }\end{array}$ & $\begin{array}{l}\text { Beef roadmap, but less buy-in. } \\
\text { Uncertainty about directionality. }\end{array}$ & None. \\
\hline \multicolumn{4}{|c|}{ 3) Pre-existing supply chain characteristics } \\
\hline Length of supply chain & Short (3 tiers) & Medium (4 tiers) & Long (5 tiers) \\
\hline $\begin{array}{l}\text { Breadth of agricultural supply } \\
\text { network }\end{array}$ & $\begin{array}{l}\text { Relatively low ( } 13.500 \text { dairy } \\
\text { farmers) ( } 3000 \text { in sustainable } \\
\text { dairy farmers groups) }\end{array}$ & $\begin{array}{l}\text { High ( } 42.000 \text { beef farmers, } \\
\text { including dairy) }\end{array}$ & $\begin{array}{l}\text { Low (Approximately } 17.000 \\
\text { wheat farmers) }\end{array}$ \\
\hline $\begin{array}{l}\text { Degree of retailer/lead firm chain } \\
\text { coordination }\end{array}$ & Most & Some & Little \\
\hline $\begin{array}{l}\text { Relative degree of trust and } \\
\text { cooperation }\end{array}$ & Moderately high & Low & Low \\
\hline
\end{tabular}

seed companies (which transfer fundamental trait research into the production of new crop varieties) because of limited demand from farmers (Interview 46). This lack of demand is compounded by the system through which new varieties of seeds are brought to market. Farmers purchase seed varieties guided by the 'recommended list' managed by the Home Grown Cereals Authority. New varieties are admitted to the list following a series of trials (which may last 7-10 years) and clear demonstration of economic benefit (Interviews 16,45 ). These procedures work against nitrogen-efficient varieties because the trials are conducted under existing fertiliser application rates, which therefore do not show the environmental and economic benefits of N-efficient varieties. A more general problem is that the lack of market demand has prevented the creation of an effective innovation system because of relatively weak linkages between upstream research and downstream use (by farmers and millers) which could be better aligned. This problem is visible in the desire of the seed company KWS: "We want to encourage the millers to be very proactive with us at the early stages of the variety, and the farmers to report back to us. We need to know farmers' and millers' experiences, and we need them to tell us and if there is trust between us, then we can promote wheat varieties much more quickly" (Podcast, 2011 ${ }^{3}$ ). Limited information flows and communication between universities, commercial breeders, farmers, millers, and bakeries hinders shared learning processes, stifling eco-innovation in wheat varieties and other crops.

\footnotetext{
${ }^{3}$ KWS Commercial director podcast on HGCA website http://www.hgca.com/ content.template/13/0/Get\%20Involved/Get\%20Involved/Get\%20Involved\%20Home $\% 20$ Page.mspx, last accessed on 15/10/2011.
}

In sum, eco-innovation in bread proceeds slowly because the supply chain is fragmented and not well-integrated. There is limited socio-cognitive coordination and no effective information exchange. Supermarkets and bread manufacturers only haphazardly engage in eco-innovation and do not pro-actively coordinate the supply chain. Only Warburtons stimulates some eco-innovation, using both economic and information exchange mechanisms.

\section{Analysis}

The case studies show that there is not a single factor that explains why, how and to what degree supermarkets stimulate upstream eco-innovation in the three cases. Rather, the differences arise from alignments of multiple factors. To make sense of this complexity, Table 1 presents an analytical summary of how the three cases relate to the three general considerations of our conceptual framework, presented in section 2: 1) motivation of supermarkets ('why' implement eco-innovation), which is divided into external pressures and internal considerations, 2) coordination and eco-innovation mechanisms ('how' to stimulate ecoinnovation), and 3) the mediating influence of (pre-existing) supply chain characteristics.

In terms of the motivation of supermarkets to engage in agricultural eco-innovation, there are some general factors as well as some specific factors that help explain differences between the three cases. By 2008 all of the major UK supermarkets had announced targets relating to improvements in the sustainability performance of their supply chains. These general orientations can be seen as a reaction to two external pressures: as a pre-emptive 
responses to postpone regulation and to defend against NGO criticism; and, as a reaction to a general perception in the industry that there was a cultural shift underway towards greater sensitivity to sustainability problems (and the rise of 'green consumers') and that this would provide a new competitive context for supermarkets. In Table 1, we focus on how these general orientations are modified by specific internal considerations and external pressures which explain differences between the three cases.

This table shows that supermarket engagement with ecoinnovation in milk has progressed farthest, because most factors point in the right direction. With regard to motivation, there is substantial external pressure from policymakers and NGOs, and not too many competing concerns; supermarkets feel responsibility for milk (own-label), which is also a strategically important product. Motivation for eco-innovation in milk is therefore relatively high. In terms of eco-innovation, supermarkets used all three mechanisms: economic, information exchange, and socio-cognitive coordination. The coordinating influence of the Milk Roadmap is particularly noteworthy and efforts to enrol the supermarkets into the initiative attest to the widespread belief that their involvement would be critical for progress. In terms of pre-existing supply chain characteristics milk also scored relatively well: compared to beef and bread, the milk chain is not long and wide, which makes coordination by supermarkets easier; dairy farms are larger than in beef, which means they have more resources and capabilities for ecoinnovation; since the mid-2000s, trust and collaboration in the milk chain have improved, which made it easier to implement the two more subtle eco-innovation mechanisms (information exchange and socio-cognitive coordination).

Eco-innovation in beef has progressed moderately, because factors point in mixed directions. With regard to motivation, pressure from policymakers and NGOs has in some respects been as strong as with milk. However, the strength of these pressures has been dampened because beef faces a greater variety of concerns and pressures, e.g. about economic viability, health and food safety (BSE, horsemeat), which compete with sustainability issues (animal welfare, biodiversity, climate change) and make it more difficult to create clear directionality. The motivation of supermarkets is moderate: while some smaller supermarkets undertake various eco-initiatives, the larger ones are not very active. This can be partially explained by weaker internal considerations, with beef being of less strategic importance in terms of enticing consumers to the store particularly for larger supermarkets, than either milk or bread. In terms of eco-innovation, supermarkets engaged less with the three mechanisms than in the milk case. Importantly, the Beef Roadmap has been less effective in creating socio-cognitive coordination than the Milk Roadmap. This is, firstly, related to difficulties in reaching consensus around the specific problem to be addressed, and, secondly, to pre-existing supply chain characteristics, in particular the high degree of mistrust in the beef chain (because of economic tensions), which hindered cooperation, elaboration of a shared vision, and buy-in to the Beef Roadmap. Moreover, the beef farming supply base is more fragmented than with milk, which also hampers opportunities to mobilise for coordinated eco-innovation initiatives. This illustrates that the effect of an instrument (roadmaps) depends on wider supply chain characteristics.

Supermarket engagement with eco-innovation in bread has progressed least, because of low scores on many factors. With regard to motivation, there is relatively little external pressure from policymakers, NGOs, or consumers. Additionally, other concerns (provenance, health and nutrition) appear to trump environmental sustainability issues. While bread is important for enticing consumers to stores, supermarkets see no responsibility for themselves to stimulate eco-innovation in the bread chain, because most bread is a branded product. Unlike the milk and beef cases, supermarkets have no direct form of interaction with wheat farmers. Interactions between the supermarkets and branded bakeries have a tendency to be adversarial, with periodic disputes over the retail price of a loaf. In the absence of any strong signal from the supermarkets, the branded bakers also take limited responsibility to stimulate ecoinnovation, except Warburtons which uses its special supply chain to work with farmers. There is no roadmap or other sociocognitive coordination mechanism in the bread chain. Economic and information exchange mechanisms are also used in limited degrees. This relates not just to limited motivation, but also to supply chain characteristics: there are few direct contacts with farmers in the bread chain, because the second tier (merchants, brokers) forms an economic buffer between farmers and downstream actors (bakers, supermarkets). This prevalence of market interactions complicates direct collaboration, information exchange, and the development of shared visions. While there are attempts to build an innovation system with regard to nitrogenefficient wheat varieties, this is complicated by the lack of demand from farmers, who face economic barriers and institutional lock-in to the 'recommended list' of seed varieties.

\section{Conclusions}

The above analysis demonstrates the usefulness of our heuristic conceptual framework for assessing the role of supermarkets in stimulating upstream eco-innovation in agri-food supply chains. Although there are clearly some specific characteristics of agri-food chains which might affect the generalisability of the findings, our general contribution lies in enriching the environmental supply chain management literature with insights from innovation studies. The incorporation of a conceptualisation of three innovation-coordinating mechanisms can therefore be used to investigate supply chain eco-innovation in other sectors, especially in those sectors where there are significant asymmetries of power between actors. While our conceptualisation of internal and external motivational factors accords with other studies, the paper's specific contribution is the identification of the three mechanisms that supermarkets used to shape upstream eco-innovation in food supply chains. By way of conclusion and to augment our analysis of the three empirical cases, we offer three more general reflections and a short discussion of areas that require further investigation.

First, the analysis suggests that enhanced supermarket involvement in distributed eco-innovation requires a shift in supply chain governance modes and the effective use of innovation coordination mechanisms: economic and information-exchange modes may need to be complemented with more subtle modes of governance, such as the collective framing of sustainability issues and the development of shared visions that reduce uncertainty and provide clarity in the orientation of eco-innovation. The cases illustrate that eco-innovation is more likely where governance structures enable more cooperative, collaborative relationships between actors.

Second, the effectiveness of various eco-innovation mechanisms is shaped by pre-existing supply chain structures. More integrated supply chains make it easier to enable promotion of ecoinnovation. The milk chain, for example, was already becoming more integrated by the mid-2000s for economic reasons. This facilitated the subsequent introduction of environmental considerations and eco-innovations. So, the success of initiatives such as best practice sharing, demonstration projects, guidance documents or benchmarking is shaped by existing degrees of collaboration and buy-in from other actors along the supply chain. A clear illustration of this point is the different degree of success of roadmaps in milk and beef chains. 
The third point relates to the economic power of supermarkets. All three cases show that supermarkets used their power to squeeze other actors in the chain (to maximise profit margins); this has changed in the milk case with the introduction of direct, longerterm contracts between supermarkets and dairy farmers based on premium prices. If supermarket squeezing leads to economic tensions within the supply chain this may have two negative consequences for eco-innovation: 1) limiting the availability of financial resources for investment in upstream eco-innovation; 2) the development of antagonistic and distrustful attitudes towards supermarkets, which may hinder the creation of effective innovation systems and information exchange.

One area that could be further elaborated in future research is the variation in supermarket strategies. The paper mainly addressed the general population of supermarkets and their engagement with eco-innovations in the three cases. More detail could be added to the cases by including individual supermarkets in the analysis, which differ in organisational cultures, capabilities, leadership, and general strategic positioning. Supermarkets positioned with a low-price orientation, for instance, tend to rely more on economic coordination mechanisms to manage their supply chain. Supermarkets which differentiate on the basis of quality or stakeholder responsibility more frequently incorporate other forms of supply chain coordination mechanisms. So, individual supermarket char- acteristics are likely to influence specific eco-innovation strategies, something that could be addressed in future research.

Another area for future research is the distinction between radical and incremental eco-innovation. The eco-innovations that were implemented in our cases were mainly incremental, introduced to improve eco-performance while maintaining existing organisation and technological arrangements. More radical innovations, such as the introduction of anaerobic digestion in the milk chain, have not been embraced. Future research could address instances of more radical eco-innovation (in other sectors or countries), and investigate if our findings with regard to the three different eco-innovation mechanisms also hold in these cases. A specific question in that regard is whether or not radical ecoinnovation can be enacted by existing chain actors (and led by existing supermarkets) or requires initiatives by new actors. This consideration also points to a possible paradox: while increased chain coordination may underpin the introduction of incremental innovations, it may also enhance the stability of existing technological and organisational arrangements, which could hinder more radical innovation.

\section{Appendix 1. Information about interviewees}

\begin{tabular}{|c|c|c|c|c|}
\hline & Type of organisation & Organisation & Interviewee details & Interview details \\
\hline 1 & Retail: supermarket & Asda & Head of sustainable sourcing & $\begin{array}{l}\text { Face to face interview and } \\
\text { site visit of head office } \\
\text { January } 2011\end{array}$ \\
\hline 2 & Retail: supermarket & Asda & Milk category director & $\begin{array}{l}\text { Face to face interview } \\
\text { February } 2011\end{array}$ \\
\hline 3 & Retail: supermarket & Morrisons & Head of agriculture & $\begin{array}{l}\text { Face to face interview } \\
\text { March } 2010\end{array}$ \\
\hline 4 & Retail: supermarket & Tesco & Agricultural champion & $\begin{array}{l}\text { Telephone interview } \\
\text { November } 2011\end{array}$ \\
\hline 5 & Retail: supermarket & Tesco & Beef technical manager & $\begin{array}{l}\text { Telephone interview } \\
\text { November } 2011\end{array}$ \\
\hline 6 & Retail: supermarket & Tesco & Climate change manager & $\begin{array}{l}\text { Telephone interview } \\
\text { February } 2011\end{array}$ \\
\hline 7 & Retail: supermarket & Tesco & Agriculture manager & $\begin{array}{l}\text { Telephone interview } \\
\text { September } 2011\end{array}$ \\
\hline 8 & Retail: supermarket & Tesco & Baked goods category manager & $\begin{array}{l}\text { Telephone interview } \\
\text { March } 2011\end{array}$ \\
\hline 9 & Retail: supermarket & Tesco & Wrapped bread category manger & $\begin{array}{l}\text { Telephone interview } \\
\text { March } 2011\end{array}$ \\
\hline 10 & Retail: supermarket & Waitrose & Agricultural manager & $\begin{array}{l}\text { Telephone interview } \\
\text { March } 2011\end{array}$ \\
\hline 11 & Retail: fast food & McDonalds & Director of supply chain Europe & $\begin{array}{l}\text { Telephone interview } \\
\text { September } 2011\end{array}$ \\
\hline 12 & Industry body & $\begin{array}{l}\text { Eblex (beef industry } \\
\text { representative group) }\end{array}$ & Senior regional manager & $\begin{array}{l}\text { Face to face interview } \\
\text { November } 2010\end{array}$ \\
\hline 13 & Industry body & Eblex & Board member & $\begin{array}{l}\text { Face to face interview } \\
\text { December } 2010\end{array}$ \\
\hline 14 & Industry body & $\begin{array}{l}\text { DairyCo/milk roadmap } \\
\text { taskforce }\end{array}$ & $\begin{array}{l}\text { Chairman of the milk } \\
\text { roadmap taskforce }\end{array}$ & $\begin{array}{l}\text { Face to face interview } \\
\text { May } 2010\end{array}$ \\
\hline 15 & Industry body & Dairy UK & Environment manager & $\begin{array}{l}\text { Face to face interview } \\
\text { March } 2011\end{array}$ \\
\hline 16 & Industry body & $\begin{array}{l}\text { National Association of British } \\
\text { and Irish Millers }\end{array}$ & Director general & $\begin{array}{l}\text { Face to face interview } \\
\text { November } 2010\end{array}$ \\
\hline 17 & Industry body & UK Federation of Bakers & Director & $\begin{array}{l}\text { Face to face interview } \\
\text { October } 2010\end{array}$ \\
\hline 18 & Representative group? & National Farmers Union & Chairman of livestock board & $\begin{array}{l}\text { Face to face interview } \\
\text { December } 2010\end{array}$ \\
\hline 19 & & National Farmers Union & Climate change advisor & $\begin{array}{l}\text { Telephone interview } \\
\text { February } 2011\end{array}$ \\
\hline 20 & & National Farmers Union & Livestock advisor & $\begin{array}{l}\text { Telephone interview } \\
\text { February } 2011\end{array}$ \\
\hline
\end{tabular}


(continued)

\begin{tabular}{|c|c|c|c|c|}
\hline & Type of organisation & Organisation & Interviewee details & Interview details \\
\hline 21 & Industry organisation & British Baker & Editor & $\begin{array}{l}\text { Face to face interview } \\
\text { November } 2010\end{array}$ \\
\hline 22 & Government & Defra & $\begin{array}{l}\text { Milk roadmap taskforce } \\
\text { Defra coordinator }\end{array}$ & $\begin{array}{l}\text { Face to face interview } \\
\text { May } 2010\end{array}$ \\
\hline 23 & Meat processor & ABP Food Group & Agriculture and livestock director & $\begin{array}{l}\text { Face to face interview and site visit } \\
\text { November } 2010\end{array}$ \\
\hline 24 & Meat processor & Rowan Foods & Purchasing manager & $\begin{array}{l}\text { Face to face interview and site visit } \\
\text { September } 2010\end{array}$ \\
\hline 25 & Meat processor & ESCA & Purchasing manager & $\begin{array}{l}\text { Face to face interview } \\
\text { November } 2011\end{array}$ \\
\hline 26 & Manufacturer: bakery & Fine Lady Bakeries & Managing director & $\begin{array}{l}\text { Face to face interview } \\
\text { October } 2010\end{array}$ \\
\hline 27 & Manufacturer: bakery & Frank Roberts Bakery & Deputy chairman & $\begin{array}{l}\text { Face to face interview } \\
\text { October } 2010\end{array}$ \\
\hline 28 & Manufacturer: bakery & Jacksons Bakery & Managing director & $\begin{array}{l}\text { Telephone interview } \\
\text { April } 2011\end{array}$ \\
\hline 29 & Manufacturer: bakery & Premier foods/Hovis & Quality director & $\begin{array}{l}\text { Telephone interview } \\
\text { June } 2011\end{array}$ \\
\hline 30 & Manufacturer: bakery & Premier foods/Hovis & Head of wheat & $\begin{array}{l}\text { Face to face interview } \\
\text { August } 2011\end{array}$ \\
\hline 31 & Manufacturer: bakery & Allied Bakeries & Director of channels & $\begin{array}{l}\text { Telephone interview } \\
\text { May } 2011\end{array}$ \\
\hline 32 & Manufacturer: bakery & Warburtons & Corporate responsibly director & $\begin{array}{l}\text { Face to face interview } \\
\text { March } 2011\end{array}$ \\
\hline 33 & Manufacturer: bakery & Warburtons & Agronomist & $\begin{array}{l}\text { Telephone interview } \\
\text { April } 2011\end{array}$ \\
\hline 34 & Manufacturing consultancy & $\begin{array}{l}\text { Baketran (Ex-Campden BRI } \\
\text { Research Institute) }\end{array}$ & Director & Telephone interview November 2010 \\
\hline 35 & Agricultural input supplier & $\begin{array}{l}\text { Growhow UK (fertiliser } \\
\text { manufacturer) }\end{array}$ & $\begin{array}{l}\text { Public affairs director } \\
\text { (and agronomist) }\end{array}$ & $\begin{array}{l}\text { Face to face interview and site visit } \\
\text { March } 2011\end{array}$ \\
\hline 36 & Agricultural input supplier & $\begin{array}{l}\text { AB sustain (livestock feed } \\
\text { producer and consultant) }\end{array}$ & Commercial director & $\begin{array}{l}\text { Telephone interview } \\
\text { February } 2011\end{array}$ \\
\hline 37 & Agricultural consultancy & $\begin{array}{l}\text { Delta innovation (rural and } \\
\text { agricultural consultancy) }\end{array}$ & Managing director & $\begin{array}{l}\text { Telephone interview } \\
\text { November } 2010\end{array}$ \\
\hline 38 & Agricultural consultancy & $\begin{array}{l}\text { ADAS (agricultural and } \\
\text { environmental consultancy) }\end{array}$ & Sustainable livestock consultant & $\begin{array}{l}\text { Telephone interview } \\
\text { September } 2010\end{array}$ \\
\hline 39 & Agricultural consultancy & $\begin{array}{l}\text { ADAS (agricultural and } \\
\text { environmental consultancy) }\end{array}$ & Food supply chain consultant & $\begin{array}{l}\text { Telephone interview } \\
\text { August } 2010\end{array}$ \\
\hline 40 & Agricultural consultancy & Independent consultant & $\begin{array}{l}\text { Beef and sheep nutrition and } \\
\text { production consultant }\end{array}$ & $\begin{array}{l}\text { Face to face interview } \\
\text { June } 2011\end{array}$ \\
\hline 41 & Agricultural consultancy & Brian Lindsay Consulting & $\begin{array}{l}\text { Managing director, dairy } \\
\text { industry consultant }\end{array}$ & $\begin{array}{l}\text { Telephone interview } \\
\text { April } 2010\end{array}$ \\
\hline 42 & Agricultural consultancy & $\begin{array}{l}\text { Reaseheath College } \\
\text { Enterprise Hub }\end{array}$ & $\begin{array}{l}\text { Knowledge transfer manager } \\
\text { for the anaerobic } \\
\text { digestion development } \\
\text { programme }\end{array}$ & $\begin{array}{l}\text { Face to face interview and site } \\
\text { visit to Reaseheath Anaerobic } \\
\text { Digester project } \\
\text { November } 2010\end{array}$ \\
\hline 43 & Research & Campden BRI & $\begin{array}{l}\text { Director of cereals and } \\
\text { cereal processing }\end{array}$ & $\begin{array}{l}\text { Telephone interview } \\
\text { November } 2010\end{array}$ \\
\hline 44 & Research & $\begin{array}{l}\text { University of Manchester } \\
\text { (previously Campden BRI) }\end{array}$ & $\begin{array}{l}\text { Senior research fellow, } \\
\text { wheat science }\end{array}$ & $\begin{array}{l}\text { Face to face interview } \\
\text { November } 2010\end{array}$ \\
\hline 45 & Research & Rothamstead research & $\begin{array}{l}\text { Director for the centre of } \\
\text { crop genetic improvement }\end{array}$ & $\begin{array}{l}\text { Telephone interview } \\
\text { February } 2011\end{array}$ \\
\hline 46 & Research & $\begin{array}{l}\text { National Association of } \\
\text { Agricultural Botany }\end{array}$ & CEO & $\begin{array}{l}\text { Face to face interview } \\
\text { February } 2011\end{array}$ \\
\hline 47 & Research & John Innes Centre & $\begin{array}{l}\text { Head of department of } \\
\text { crop genetics }\end{array}$ & March 2011 \\
\hline
\end{tabular}

\section{References}

Audsley, E., Brander, M., Chatterton, J., Murphy-Bokern, D., Webster, C., Williams, A. 2009. How Low Can We Go? An Assessment of Greenhouse Gas Emissions fron the UK Food System and the Scope to Reduce Them by 2050. WWF-UK and Food Climate Research Network.

Bijker, W.E., Hughes, T.P., Pinch, T. (Eds.), 1987. The Social Construction of Technological Systems: New Directions in the Sociology and History of Technology. The MIT Press, Cambridge, Massachusetts.

Borup, M., Brown, N., Konrad, K., Van Lente, H., 2006. The sociology of expectations in science and technology. Technol. Anal. Strat. Manag. 18 (3-4), 285-298.

Dairy UK, 2012. The White Paper212: a Report on the UK Dairy Industry.

Defra, 2010. Food 2030. HM Government, Department for Environment, Food, and Rural Affairs.

Defra, 2012. UK Milk Prices and Composition of Milk 2012. HM Government, Department for Environment, Food, and Rural Affairs.
Dolan, C., Humphrey, J., 2000. Governance and trade in fresh vegetables: the impact of UK supermarkets on the African horticulture industry. Glob. Trade 37 (2), 147-176.

Dosi, G., Nelson, R.R., 1994. An introduction to evolutionary theories in economics. J. Evol. Econ. 4 (3), 153-172.

Eblex, 2009a. In the Balance? The Future of the English Beef Industry. http://www. eblex.org.uk/documents/content/publications/p cp inthebalance.pdf.

Eblex, 2009b. Change in the Air: Beef and Sheep Production Roadmap Phase 1. English Beef and Lamb Executive, Agriculture and Horticulture Development Board, Kenilworth.

Eblex, 2010. Testing the Water: Beef and Sheep Production Roadmap Phase 2. English Beef and Lamb Executive, Agriculture and Horticulture Development Board, Kenilworth.

Fine, B., Heasman, M., Wright, J., 1996. Consumption in the Age of Affluence. Routledge, London.

Freeman, C., Soete, L., 1997. The Economics of Industrial Innovation, third ed. The MIT Press, Cambridge (Mass). 
Foster, C., Gee, S., May 2013. Playing for High Steaks: Market Structure and Purchaser-led Sustainability Initiatives in the UK Beef Sector. MIoIR. Working paper 75.

Gambetta, D. (Ed.), 1988. Trust: Making and Breaking Cooperative Relations. Basil Blackwell, New York.

Gereffi, G., Humphrey, J., Sturgeon, T., 2005. The governance of global value chains. Rev. Int. Polit. Econ. 12 (1), 78-104.

House of Commons, 2012. Milk Prices from 2005, Research Briefing for the House of Commons available at: http://www.parliament.uk/briefing-papers/SN00546.

Howells, J., 1995. A socio-cognitive approach to innovation. Res. Policy 24, 883-894.

Jackson, B., Lee-Woolf, C., Higginson, F., Wallace, J., Agathou, N., 2009. Strategies for Reducing the Climate Impacts of Red Meat/Dairy Consumption in the UK. WWF and Imperial College.

Kolk, A., Pinkse, J., 2007. Multinationals' political activities on climate change. Bus. Soc. 46 (2), 201-228.

Lundvall, B.A. (Ed.), 1992. National Systems of Innovation: towards a Theory of Innovation and Interactive Learning. Pinter Publishers, London.

Malerba, F., 2002. Sectoral systems of innovation. Res. Policy 31 (2), 247-264.

Omta, S.W.F., 2001. Chain and network science: a research framework. Chain Netw.

Sci. 1 (1), 1-6.
Powell, W., Grodal, S., 2005. Networks of innovators. In: Fagerberg, J., Mowery, D., Nelson, R. (Eds.), The Oxford Handbook of Innovation. Oxford University Press, Oxford, pp. 56-85.

Seuring, S., Müller, M., 2008. From a literature review to a conceptual framework for sustainable supply chain management. J. Clean. Prod. 16 (5), 1699-1710.

Simons, D., Francis, M., Bourlakis, M., Fearne, A., 2003. Identifying the determinants of the value in the UK red meat industry: a value chain analysis approach. Chain Netw. Sci. 3 (2), 109-121.

Srivastava, S., 2007. Green supply-chain management: a state-of-the-art literature review. Int. J. Manag. Rev. 9 (1), 53-80.

Van Bommel, H.W.M., 2011. A conceptual framework for analysing sustainability strategies in industrial supply networks from an innovation perspective. J. Clean. Prod. 19, 895-904.

Van den Bergh, J.C.J.M., Faber, A., Idenburg, A.M., Oosterhuis, F.H., 2008. Evolutionary Economics and Environmental Policy: Survival of the Greenest. Edward Elgar, Cheltenham.

Van Lente, H., 1993. Promising Technology: the Dynamics of Expectations in Technological Development. PhD thesis, Twente University. Eburon, Delft.

Yin, R.K., 1994. Case Study Research: Design and Methods, second ed. Sage Publications, Thousand Oaks, CA. 